\title{
Elementary Students' Perceptions of Learning Environment Based Digital Games in EFL
}

\section{* Dr. Fayiz Aldhafeeri \\ * Dr. Nawal Alothman}

\section{Introduction and Background}

Digital games have been used in education since 2011, but there is still doubt as to their effective instructional use. However, the use of well-designed digital games is becoming increasingly popular (Schneider, 2012; Frederick, 2009; Yang, 2012; Fromme \& Unger, 2012) with the assumption that instructional games can create an engaging learning environment and that they can be motivating. In addition, there is still little consensus regarding the essential characteristics of instructional games. Dickey (2011), in this context, suggested that a digital gamebased instruction can boost interest and involvement by stimulating excitement and competition, giving students the opportunity to synthesise and practice skills in a broad context - broader than the ones offered by role plays or group discussions in traditional learning environments. Instructional games can also

\footnotetext{
* Department of Curriculum \& Instruction College of Education, Kuwait University

* Department of Curriculum \& Instruction College of Education, Kuwait University
} 
give students feedback about their own individual level since answers are scored right or scored better or worse. Burguillo (2010) assures that digital games are fun, anyway.

Literature on digital games and the learning environment is limited, but what exists implies that if teachers could pair instruction content with certain game features, then they can make best use of digital games to engage users and achieve desired instructional goals in a highly motivating environment (Yang, 2012).

In this vein, the creation of professional journals in simulation, gaming and experiential education, and the increased research activity in assessing games as instructional mediums, has encouraged more researchers, teachers, and trainers to identify the legitimacy and benefits of using digital games in the classroom. Using such games to enhance the learning environment perceptions of students and achievement motivation (Burguillo, 2010).

Research pertinent to digital games instruction is in need of a conceptual framework to support the use of instructional games in the classroom environment. There has been too little research in this area where an instructional game has been systematically studied to measure the changes that occur in a classroom environment. Therefore, more research is needed to analyze and understand the perceptions and experiences of students using instructional games in a classroom environment.

On the other hand, insights and implications from instructional gaming and classroom environment research, together with the theoretical foundations and practical implications of Rogers' experiential learning theory and Moos' theory of learning environment, can provide powerful perspectives from which to view how digital games impact students' experiences in, and 
perceptions of, the classroom learning environment (Liu \& Chu, 2012). These powerful insights and implications can be harnessed to identify the critical characteristics of learning environments that instructors should consider when looking to design motivating digital game-based instruction experiences. This is true in as much as a game is designed to cling to educational outcomes, potentially leading to an experience that provides a positive and motivating opportunity for students to become increasingly involved in the classroom and show increased responsibility for their learning. Gaming, therefore, is firmly grounded in experiential learning (Eow, 2010; Chen, 2012).

Experiential education is one manifestation of active learning that can, in turn, take on several manifestations including role-playing, small group discussions, or intricately designed simulations, such as instructional games. These activities are designed to engage the learner in the experience, but more importantly, efforts must be made to reflect on the connections between the learning objectives and the experience itself, i.e., between the game objectives, the experience, and achievement motivation. Achievement goals and perceived motivational climate are two important constructs in achievement goal theory, and they play critical roles in student motivation and behaviour. Optimizing the motivation of all students is clearly an important outcome for elementary school students. Research has shown, however, that as children grow older their interest and participation in child education decreases (Sylven \& Sundqvist, 2012). Traditionally, these two constructs, achievement goals and motivational climate, have been examined separately. Achievement goal theory assumes that the individual is an intentional, goal-directed organism 
operating in a rational manner (Baek, 2010). This approach contends that the goal of action in achievement settings is the demonstration of ability, with Liu (2011) proposing the existence of two goal states of involvement, namely, task and ego.

Achievement goals, also known as dispositional goal orientations, have been contrasted as task orientation and ego orientation. Task orientation involves the goal of developing one's ability through learning or task mastery, while ego orientation implies demonstrating one's superiority over others. Research examining achievement goals and the associated patterns of cognition, affect, and behaviour reveals that task orientation is associated with adaptive motivational patterns, whereas ego orientation is associated with maladaptive motivational patterns (Bourgonjon et al., 2011; Filippidis \& Tsoukalas, 2009; Wang \& Liao, 2001; Yang, 2012). Adaptive motivational patterns include working hard for success, showing intrinsic interest in learning, attributing success to effort, and persisting in the face of difficulty. In contrast, maladaptive motivational patterns include avoiding challenging tasks, attributing failure to ability, and giving up easily in the face of difficulty (Treasure, 1997).

Perceived motivational climate refers to student perceptions of achievement goals stressed by the teacher (Bourgonjon et al., 2011). Unlike achievement goals, which are viewed as a dispositional variable, this construct is considered situational because what the teacher says and does can influence the degree to which task and ego orientation are perceived as salient in the classroom. Students perceive the classroom as a task or an ego-involved climate and, consequently, evoke qualitatively different motivational patterns. Available research has consistently shown that perceptions of a 
task-involved climate are associated with measures of intrinsic motivation and the belief that success is a result of effort. While perceptions of an ego-involved climate are associated with decreases in intrinsic motivation and the belief, that success is caused by ability (Ames, 1992; Treasure, 1997).

Therefore, it is assumed that an individual is task or ego involved in an achievement setting because of both dispositional and situational determinants. Specifically, the predisposing tendency to be task or ego involved in achievement contexts is thought to be reflected by an individual's dispositional goal orientation. This is while the salience of performance and mastery oriented cues in the achievement context are situational criteria that may alter the probability of adopting a particular state of involvement (Meece et al., 1988).

In this way, Meece et al. (1988) explained that students engage in activities that help them create their own intellectual structures and examine them to make a better sense of the world around them. Experiential education, including game-based instruction, changes the traditional learning environment and places students and their experiences at the centre of the learning process.

Due to confusion in terminology, it should be mentioned that descriptive terms, such as "simulation games", "game simulations", "gaming simulations, "gaming", "games with simulated environments", "instructional games" and "educational games", have been quite confusing for researchers manipulating games as educational tools (Devlin \& Nancy, 2010). Therefore, clarification of this terminology is necessary.

Simulations or game simulations represent an actual social system outside of the classroom, 
specifically designed as complete with realistic goals, objectives, resources, and consequences (Swearingen, 2011). Games, however, are realistic or contrived interactive environments, where there is competition, rules, rewards and a specific outcome (Frederick, 2010; Devlin \& Nancy, 2010; Swearingen, 2011).

An instructional game is any game that has the primary purpose to teach rather than to entertain; thus, they imbue the learning environment and experiences with competition, risk and scoring (Filippidis \& Tsoukalas, 2009).

Some games may be intellectually challenging, but are not designed to teach or enhance learning in an educational setting (Burguillo, 2010). Other games are educationally beneficial, but may not be designed to replicate a "real world" social system outside of the classroom. The most important aspect of effective educational games is that they must correspond with the learning outcomes of the course and have meaningful learning objectives, either embedded throughout the playing of the game or addressed during post-game reflection (Eow et al. 2010; Liu, 2011; Fromme \& Unger, 2012).

Furthermore, digital games are those which are popularly familiar (such as Tutpup Spelling, Fit Brains game, ProProfs Brain games, and so on) but are manipulated to specifically cover the content of a particular course (Frederick, 2009; Schneider, 2012; Fromme \& Unger, 2012). Yang (2012) explains that, "[digital games based instruction] are those games that are deliberately developed to provide a digital contentfree instructional structure on which can be loaded locally relevant content" (p.198). These have numerous educational benefits, such as helping students generate awareness about current issues, discover new insights, 
learn basic facts (lower-level thinking skills), and can be further used to apply higher order thinking skills such as integration, synthesis, and problem-solving (p.104). Furthermore, digital games are less timeconsuming to design as the basic structure of the game, such as the subject area and rules of play, can be changed to coincide with the intended course goals and objectives.

As noted earlier, digital game-based instruction is (theoretically) firmly grounded in experiential learning. Given favourable conditions and a supportive environment, Rogers believed all humans are inherently capable of obtaining some level of selfactualization (Frederick, 2010). In this sense, Rogers viewed learning on a continuum ranging from cognitive (meaningless) to experiential (significant). Cognitive learning includes academic knowledge such as memorizing or spelling words. Experiential learning refers to activities that are applied and will lead to some type of personal growth or change, such as the use of language in real-life daily communications (Chen, Zhi-Hong et al., 2012; Yang, 2012; Sylven \& Sundqvist, 2012). In experiential learning, there are four qualities which facilitate and enhance the learning process. It (a) requires learners' personal involvement; (b) it is based on direct practical, social, personal or research problems that relate to the learners; (c) it is self-evaluated by learners; and (d) it has pervasive effects on learners (Baek, 2010).

In his humanistic approach to understanding human personality, and learning by extension, Swearingen (2011) referred to traditional, rigid approaches to education as "self-defeating systems" that prescribe too many limitations and restrictions, resulting in a loss of creativity and curiosity that ultimately affects students' learning and development. 
Baek (2010), in his understanding of digital gamebased instruction, suggests that education moves from relying too heavily on the cognitive aspects of student learning to the more significant types of learning as determined by students' own interests and curiosities.

In experiential education, the role of the teacher is not to present all the facts, but to facilitate learning by enhancing interpersonal relationships through a supportive learning environment that induces achievement motivation. Fraser (2002) suggested five strategies for facilitating learning: (a) create a positive climate for learning, (b) clarify the purposes of the learners, (c) organize and present learning resources, (d) balance the intellectual and emotional aspects of learning, and (e) share feelings and thoughts with learners, but not dominate the conversation or the learning process. This type of climate, classroom environment or setting encourages interpersonal relationships, inducing students to become incrementally self-directed learners (Fraser, 2002; Rodgers, 2002).

The assumption is that Meece and Blumenfeld (1988) believed that humans are trustworthy individuals who depend on relationships and social interactions. They believe our lives move from dependence to independence, and our natural tendency is to move towards some higher level of development (Treasure, 1997; Rodgers, 2002). Relationships permeate every aspect of society, helping us learn what is expected, how to interact with others and how to exist in the world. In educational settings, these psychological and social relationships influence the teaching and learning process, and it is through these social interactions that students realize their potential (Filippidis \& Tsoukalas, 2009). Rodgers (2002) stated, "The facilitation of significant learning rests upon 
certain attitudinal qualities which exist in the personal relationship between the facilitator and the learner" (p.112). In any educational setting, personalities, emotions and reactions can enhance or hinder the learning environment, resulting in positive or negative learning experiences. Therefore, experience, engagement and reflection significantly influence one's learning, and the learning environment has a direct impact on students' academic success potentially determined by achievement motivation (Wang \& Liao, 2011; Liu, 2011). According to Eow (2010), research has shown that non-supportive, critical, and negative classroom 'climates' have adverse physiological and psychological effects on learners.

Furthermore, Rodgers (2002), working on the major works of Dewey and Rogers, suggested that the ultimate goal of education is the production of a fully functioning person, and described this as a person whose most prominent characteristic is an "increasing openness to experience... [who is] able to listen to themselves and to others and to allow themselves to experience what is happening without feeling threatened" (p.76).

Therefore, each instructor, each classroom, and each experience presents new challenges to the students, and well-adjusted, knowledgeable students can succeed and learn in any environment. However, Rogers maintained that an experiential, supportive, challenging and compassionate learning environment would lead to enhanced student achievement where students feel they can take a risk and explore their interests within their own realms of reality (Rodgers, 2002; Burguillo, 2010). In this very respect, it is the educator's responsibility to facilitate this development process by establishing a sense of community through social and interpersonal relationships to create 
favourable conditions from which learning can occur (Rodgers, 2002).

There have been very few studies that have drawn implications from Rogers's humanistic approach to personality and learning which cover educational games as an aspect of experiential education, citing Kolb and Dewey, with references to Piaget and Lewin (Liu \& Chu, 2010; Dickey, 2011; Bourgonjon et al., 2011; Fromme \& Unger, 2012; Schneider, 2012).

The use of digital educational games is commensurate with all four of Rogers's qualities for facilitating and enhancing the learning process in experiential education: (a) games require the learners' personal involvement; (b) they can be based upon direct practical, social, personal or research problems that relate to learners; (c) they allow students the opportunity to evaluate their own progress and success; and (d) they make lasting impressions on learners because games are unique, fun and challenging (Sylven \& Sundqvist, 2012).

Experiential education, specifically games, reverses the traditional teaching and learning model where students passively receive information from the instructor and are then tested on their mastery of the material. In instructional designs involving the use of games, children are placed in the centre of the issue where they must take action first, apply their knowledge, and then generalize to other contexts (Frederick, 2010; Yang, 2012). The fundamental concept of Rogers's theory of experiential education is this emphasis on the learner, and well-designed games begin with the students' own experiences, knowledge, and beliefs. When viewed in connection with educational games, Rogers's theory provides an interesting approach from which to plan, design, implement, and reflect on the use of games and how the 
classroom environment changes when games are introduced.

It is incumbent, therefore, to provide an overview of research on the classroom environment. Over the last forty years, extensive analysis and evaluation on the impacts of classroom environments have influenced the teaching and learning process (Fraser, 2002).

Meece et al. (1998) stressed that the learning environment has a strong influence on learner outcomes and plays an important role in improving the effectiveness of learning, from the level of the institution down to the level of the individual classroom. Therefore, instructors who seek to improve the effectiveness of teaching and learning should view the learning environment as a critical component of students' overall educational experience (Fraser, 2002).

The majority of research on classroom environments has been conducted in elementary and secondary school settings (Treasure, 1997; Frederick, 2009; Devlin \& Nancy, 2010; Schneider, 2012). Prior to the late 1970 s, few studies attempted to analyze the impact of the learning environment in higher education classrooms (Eow, 2010). In these studies, researchers emphasized the quality of the instructor rather than the social, psychological and intellectual development of students (Liu, 2011).

Over the past twenty years, researchers have switched their focus towards the college classroomlearning environment and its influence on students' learning, social development, satisfaction and personal growth. Most researchers study students' perceptions of psychosocial dimensions of the classroom environment based upon Moos's conceptual framework (Fraser, 2002; Filippidis \& Tsoukalas, 2009; Dickey, 2011; Bourgonjon et al., 2011). Fraser (2002) offered further 
explanation, "Classroom environment dimensions have been used as criterion variables in research aimed at identifying how the classroom environment varies with such factors as teacher personality, class size, grade level, subject matter, the nature of the school-level environment and the type of school" (p.13).

Researchers are interested in students' perceptions and experiences within a classroom environment (Liu, 2011). By focusing on students' perceptions, the researchers are allowed to see the classroom environment "through the eyes of the participants, rather than through the eyes of an external observer" (Treasure, 1997; Frederick, 2010).

Much of the research in the area of the classroom environment has been conducted on the role of the learning environment in meeting student-learning outcomes in the classroom, throughout the curriculum, at the institutional level, and in terms of students' perceptions of this environment (Treasure, 1997). Fraser (2002) stated, "The strongest tradition in past classroom environment research has involved investigation of associations between students' cognitive and affective learning outcomes and their perceptions of psychosocial characteristics of their classrooms" (p.8). Although Fraser (2002) studied the impacts of technology on learning environments, few studies have used classroom environment instruments to measure the impact of an educational innovation on students' perceptions, satisfaction, and cognitive development (Fraser, 2002). This research investigated comparisons of students' and instructors' perceptions of their actual and preferred learning environments (Fromme \& Unger, 2012) in traditional and web-based instructional settings. Some researchers focused on person-environment fit studies, which determine whether students perform more effectively in their 
preferred learning environments (Yang, 2012). New research is also emerging on graduate level classroom learning environments (Chen, Zhi-Hong et al., 2012; Sylven \& Sundqvist, 2012). Moreover, with the increase in web 2.0-based courses, research is just beginning on the impacts digital education and online games have on the learning environment (Dickey, 2011; Wang \& Liao, 2011; Sylven \& Sundqvist, 2012). Most of this research has indicated significant differences in students' perceptions of classroom environments based on the type of institution and their academic disciplines, gender variations, course type, and so on.

\section{Purpose of the Study}

The purpose of this study was to describe and interpret students' perceptions and experiences in a learning environment that included a digital game as a teaching and learning tool for enhancing achievement goals.

\section{Research Problem}

Digital games are now presented almost in every house, especially with young children. Therefore, learning environment, such as a classroom, should be examined against working effectively with emerging digital media. Additionally, Students' perception of their learning environment has been identified as quite an important variable for learning to occur and, in fact, that it cannot be ignored. Research designs and instructional designs incorporating the perceptions of students from their points-of-view allow data to be collected that outside observers could miss. Students have experiences from many different classrooms making them accurate judges of the learning environment relating to them. However, an objective 
observer is valuable as they can analyze students' perceptions and experiences within the learning environment. In learning environment research, these perspectives are referred to as alpha press and beta press. Alpha press is the learning environment as viewed by an outside observer and beta press is the learning environment as viewed by internal participants (Treasure, 1997). In a well-designed study, both perspectives should be taken into consideration to achieve a more accurate description of the learning environment (Filippidis \& Tsoukalas, 2009; Fromme \& Unger, 2012). Objective indexes are appropriate measures of the learning environment, but there is also a need to tell the whole story of students' experiences and provide supporting evidence that the instrument is accurately measuring students' perceptions.

\section{Research Questions}

Three specific research questions were formulated to handle the objective of the study, which are:

1. What are elementary students' perceptions and experiences in a classroom environment that includes a digital game for teaching and learning?

2. How is students' learning influenced by a digital game in the classroom?

3. How are students' achievement goals enhanced by a digital game in the learning classroom?

\section{Research Methodology}

Description of Participants and Setting

The participants in this study were students enrolled in a $6^{\text {th }}$ grade in a Kuwaiti elementary school in $\mathrm{Al}$ 'asema, studying an EFL course during the winter of the 2011/2012 academic year. The course was required for all Kuwaiti elementary $6^{\text {th }}$ graders. There were a total of (30) participants which included both genders in equal distribution $\left(6^{\text {th }}\right.$ grade: 15 boys and 15 girls, Mean age $=10.00$ years, $\mathrm{SD}=0.62$ ). The mean 
and standard deviation of socioeconomic status (SES) for the participants were 5.99 and 0.88 for boys and girls, respectively. The SES was determined by averaging the years of the parents' education, a technique suggested by Lecompte et al. (1992) and Camilli et al. (2006). The mean and standard deviation of SES were computed based on the following criteria: $1=$ no schooling or some elementary school; $2=$ completed elementary school; $3=$ some secondary school; $4=$ completed secondary school; $5=$ some postsecondary education; and $6=$ completed college or university education. The ethno-racial composition of the sample was (96\%) indigenous Kuwaiti citizens, (3\%) Arab labourers in Kuwait, and (1\%) Asian labourers. Parental and student permission to participate was received from all participants.

All of the students' assignments were part of the regular design of the course. Students' opinions, perceptions and observations about the digital game did not have any effect on their final grades and subjects in the study were randomly selected. The class met for (50) minutes, five days a week, with both their EFL instructor and the researchers as peer-observers. The room was an important factor in determining how the overall setup of the digital game was designed. This room was designed to seat approximately (30) students and was air-conditioned. Students sat in chairs with attached desks that could be folded up or down as necessary. IPads were distributed during the lessons with the digital game installed. There was a large desk for the instructor at the front of the room that was equipped with an electronic whiteboard, a screen, a computer, a VCR, and a variety of other technological equipment. 


\section{Data Collection Techniques and Measures}

Three sources of data were manipulated: 1) students' reflection assignments from their reflective practice sheets; 2) the instructor's reflective journals; and 3) the researchers' peer-observers' feedback and reflection checklists and notes. The study, therefore, manipulated a qualitative research method. In addition, the study also manipulated a learning environment perceptions questionnaire and achievement motivation scale, thereby making use of quantitative research methods - these were administered before and after study. A personal datasheet was used to gather information about students' backgrounds, were students responded to questions relating to age, gender, grade in school, race, and socioeconomic status (SES).

\section{Achievement Goals Questionnaire}

The present investigation used the task and ego orientation subscales from the Swearingen (2011) study to examine achievement goals in relation to perceived motivational climate in an EFL learning environment. Participants completed the task and ego orientation in a learning English as a foreign language questionnaire developed by the researchers. This scale consists of thirteen items reflecting task- or ego-oriented definitions of success in EFL learning contexts. The items were prefaced with the heading "I feel really successful in EFL classes when...." Exemplary items of task orientation were, “...I work really hard", “...I learn a new skill by trying hard". Exemplary items of ego orientation were, "...the others can't do as well as me", "...I'm the only one who can do the play or skill".

Participants rated each item on a 5-point Likerttype scale ranging from strongly disagree (1) to strongly agree (5). Reliability coefficients (Cronbach's 
alpha) for task and ego orientation were .74 and .89, respectively.

\section{Perceived Motivational Climate Scale}

To assess the perceived motivational climate, participants completed a questionnaire - the Perceived Motivational Climate in Learning English as a Foreign Language (PMCEFL), developed by the researchers and grounded in previous learning environment perception questionnaires (Liu \& Chu, 2010; Dickey, 2011). This scale consists of 11 task-involved and 14 ego-involved statements.

Participants responded to statements beginning with the stem "In EFL learning classes..." by indicating their level of agreement with 25 statements concerning their perceptions of the motivational climate of the class on a 5-point Likert-type scale, ranging from strongly disagree (1) to strongly agree (5). Examples of the 11 task-involved statements were: "All students are encouraged to do their best" and "The teacher wants me to improve my score and not worry about anyone else's score". Examples of the 14 ego-involved statements were "Outperforming classmates is important" and "Students feel left out if they are not among the best". The PMCEFL has demonstrated acceptable validity and reliability (Kolenikov et al., 2010) and has been successfully adopted in EFL education. Reliability coefficients (Cronbach's alpha) were .76 for the perception of a task-involved climate and .82 for the perception of an ego-involved climate.

\section{Findings}

In this study, both the empirical and reflective methods of qualitative and quantitative research were employed. Open, axial, and selective coding was used on textual data gathered from students' reflection assignments, the teacher's research journals, and 
feedback from the peer observers. Furthermore, descriptive statistics on students' achievement goals and perceived motivational climate were extracted, statistically treated, and presented in Table (1).

\section{Findings from Reflective Assessments}

Data were coded to illustrate common themes from the overall classroom experience as a whole. The researchers coded all of the reflection assignments of students, the teacher's reflective practice journals, and peer observers' feedback. Then, the researchers used open, axial, and selective coding techniques and combined these with VAN Manen (1990) selective and detailed approaches for isolating themes in phenomenological studies. Six major themes, listed from most to least frequently mentioned, were:

1. Environment: Included all references to the learning environment and setting.

2.Activity: Included all of the different digital activities and games in the course, including GenkiEnglish Games (downloaded from App Store and from GenkiEnglish.com and adapted for the 6th grader's English course). GenkiEnglish Games were the most frequently mentioned activity.

3.Student Characteristics: Included all of the descriptive characteristics of the students, including their attitudes, personalities, behaviours, and backgrounds. Most of these descriptions were from the students' reflective practice sheets and the teacher's reflective journals, although some students mentioned these characteristics in their reflections.

4. Knowledge: Included descriptions of what students learned academically, personally, and professionally.

5.Instructor Characteristics: Included all of the descriptive characteristics of the instructor, including my attitude, personality, behaviour, and background. 
Most of these descriptions were from the students' reflection assignments.

6. Structure: Included all references to the overall structure of the course, including the attendance policy (attendance, tardiness, and absences) and assignments (homework, quizzes, and in-class exercises).

These observations were based on this particular learning environment at a time where students are engaged in their digital games. Student responses commonly overlapped into several of these themes, illustrating that these themes are inter-related and contextual.

Trying to divide students' perceptions and experiences into themes and categories seems artificial, but it is necessary in trying to understand a phenomenon as complex as human behaviour. Therefore, analyses of these themes are given below:

\section{Analysis of Theme \#1: Digital Games Learning Environment}

Most participants' responses (originally written in Arabic to make it easier for them to express themselves) dealing with the environment or classroom climate suggested the emergence of three sub-themes. Students described the digital games learning environment as: (1) interactive, catering to individual variations, (2) interesting and motivating, and (3) fun. Each of these sub-themes will be discussed below:

1. Interactive \& Personal: Group work created a relaxed, interactive environment where students were encouraged to share ideas during the digital game and create friendships. Students consistently mentioned all of the different group activities and discussions. Working in groups or pairs allowed the students to meet each other and work together to learn from someone else's point-of-view. Typically, 
most students commented what is tantamount to this statement: "I really like the way we divide into smaller playing groups online, to work on exercises or questions dealing with the subjects of the day. It helped me get over my shyness. It also gives me a chance to get to interact with other people and to know their opinions".

As well, students appreciated the opportunity to digitally connect with others in the class. They perceived this type of environment as less risky and stressful since they were able to discuss their opinions with their peers before discussing ideas with the whole class.

2. Interesting and Motivating: This type of interactive digital learning environment appeared to be motivating and interesting to students, given their age and developmental stage. For many students, this was a positive characteristic of the class. Most students commented what is tantamount to this statement: "I began to like English this semester more than ever before because I can play on my iPad while I learn".

3. Fun: Many students described the digital games learning environment as fun, especially when referring to the games and activities they participated in throughout the semester. Most students explained that it was fun being a student in that class because of the digital games and the projects, and the individual things they took part in.

This analysis provided a general overview of the students' descriptions of their perceptions of the learning environment. Students described the overall digital games learning environment as interactive, personal, interesting and motivating, and fun. They appreciated the different approaches to teaching and learning in the classroom. 


\section{Analysis of Theme \#2: Activity}

The researchers intentionally redesigned the course around a series of activities where students could apply their knowledge and integrate course concepts on a regular basis. The "Activity" theme included any active learning technique used in the class and emerged in every student's reflective practice sheet. Students recalled at least one activity and explained what they learned from it. Digital games and activities seemed to be the most memorable. Twentynine of the thirty students mentioned GenkiEnglish in their reflection sheets. The sub-themes that emerged from the students' reflections about activities, specifically GenkiEnglish activities, were: (1) realistic, (2) fun, (3) competitive, and (4) motivating.

1. Realistic: Students in this class were particularly interested in "real

world" activities and experiences. They were keen to apply language learned to a realistic setting involving the game as a technique for learning English. GenkiEnglish gave them this experience, and they seemed appreciative of the chance to test their skills. Most students commented: "We were able to take all the information that we learned all week long and apply it to our English class that we were supposed to be learning and using".

2. Fun: "Fun" emerged as a popular comment when students described their experience with the class digital games activities. Students' comments suggest the games had an influence over their decisions to pursue learning English on their own at home and helped them identify their strengths.

3. Competitive: Within the game, opportunities existed for students to be cooperative and competitive at the same time. These students worked digitally and 
collaboratively in groups with their peers, but they mostly seemed to enjoy the competition with other groups.

They thrived in the competitive atmosphere the digital games and technology brought to the classroom. One typical comment from students' responses stated: "Out of everything we did this semester, I enjoyed online games the most. It provided a sense of competition and fun".

4. Interesting and Motivating: The GenkiEnglish games provided a motivating and interesting classroom experience for the students. They understood the connections between the purpose of the game and the content of the course, and they enjoyed a new way of learning in the classroom. One student commented: "I also enjoy participating in the "GenkiEnglish" games. It is something fun that is not traditional and I think it is enjoyable to the whole class while we still learn".

\section{Analysis of Theme \#3: Student Characteristics}

Attitudes, personalities, and behaviours affect any environment and have an impact on the potential for establishing relationships (Fraser, 2002). The classroom environment is no different. It is susceptible to students' personalities and behaviours, and these attitudes have an influence on the overall learning environment. In this class, there was a sharp distinction between those who wanted to succeed and those who appeared not to care.

The observations of these students' attitudes, personalities, and behaviours clearly emphasized the problems the researchers and instructor experienced while connecting with them early on in the semester. The observations revealed the frustrations and personal struggles of working with students who appeared unwilling to try. Approximately half of the students in 
this class did not seem to have the motivation or desire to participate. The instructor and researchers' opinions about these students were not just their own observations. Students openly wrote about their feelings and attitudes towards school in their reflective sheets.

However, not all of the students were as unmotivated and lacking in focus. Many talented students attended class regularly and participated in all of the activities and assignments. Students described how the design of the class environment motivated them to want to attend class.

\section{Analysis of Theme \#4: Instructor Characteristics}

The instructor plays a critical role in creating a supportive digital learning environment (Frederick, 2009; Schneider, 2012). His teaching style, personality, attitude, and behaviour affected the learning environment and overall classroom community just as much as the students' characteristics. In reviewing the students' reflection sheets, three general sub-themes emerged from the students' descriptions of the teaching style: (1) enthusiasm, (2) personal contact, and (3) professional knowledge. These three sub-themes are discussed below:

1. Enthusiasm: It was observed that the instructor loved teaching the digital game-designed English course. She would always come to class in a good mood and made effort to talk to individual students before the class. She made every effort to approach the day's lesson with enthusiasm and energy, hoping to motivate and inspire students to do the same.

2. Personal contact: Establishing a relationship with the teacher was important for these students. They wanted an instructor who knew their names and interests and put students first. 
3. Professional knowledge: Teachers need to be knowledgeable about their field. The teacher sometimes used her own personal experiences to explain and present the language and games. She noticed students listened and seemed more attentive when she described her personal experiences working in the field. An instructor sets the tone for a digital learning environment.

\section{Analysis of Theme \#5: Structure}

The final theme in the overall digital games learning environment was structure. This included any references to classroom management issues such as attendance, tardiness, homework, exams, and in-class assignments.

Students also commented on the attendance policy. They felt they should be able to decide whether or not to attend class, but they found the new instructional design and classroom setting intriguing and interesting.

Another part of the structure included homework, exercises, and in-class assignments. Unique, interesting assignments, involving further home use of the GenkiEnglish games were created, which seemed to have an impact on students' experiences and perceptions in the classroom.

\section{Analysis of the GenkiEnglish Game}

Most students were excited about the opportunity to do something new, exciting, and different. There was collaborative and cooperative work; before they started playing the game digitally, their teacher had placed them in groups based on their personal interests and linguistic abilities. Students had completed a reflection assignment earlier in the week which explained the GenkiGames as fun, interesting and yet instructive, providing indelible words and structures in English which they could retain and retrieve much more easily 
than using the traditional method. Figure (1) shows some screen shots of the GenkiEnglish games and teacher explanations of using them on digital units.
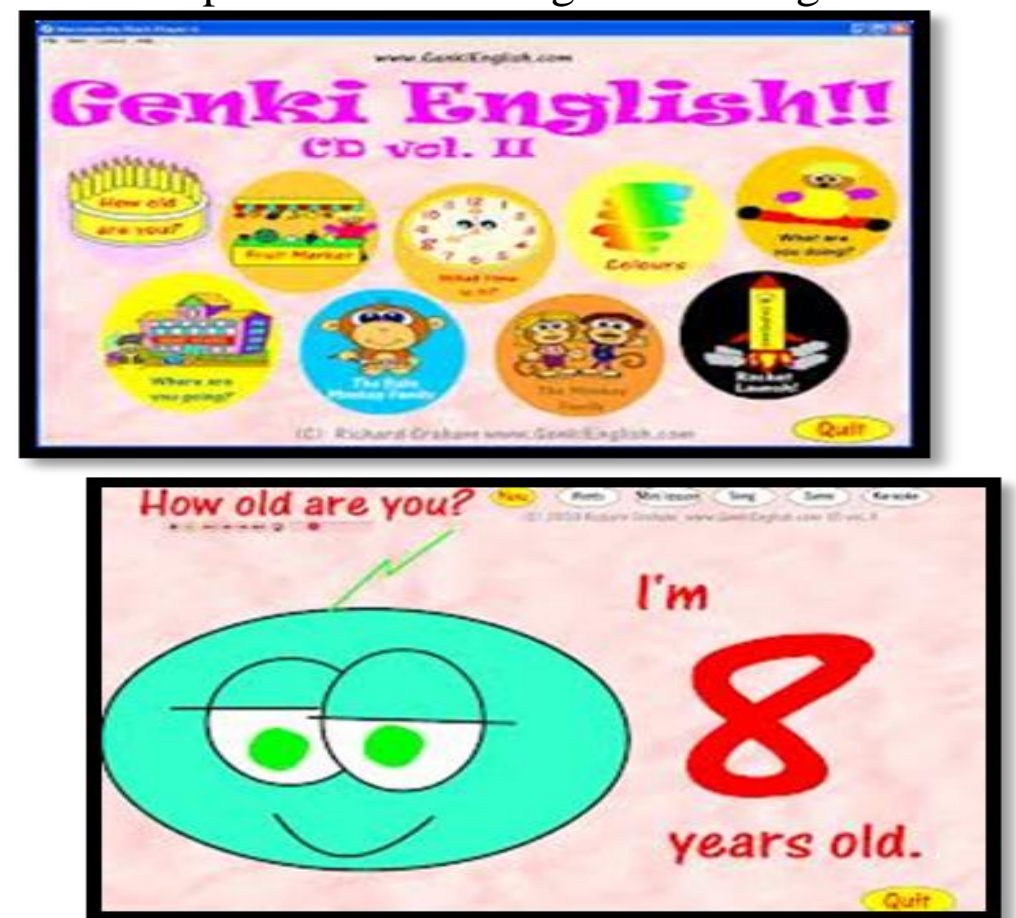

Figure (1): Screen Shots of GenkiEnglish Games

Each student worked on an iPad or a laptop to access the online games. Individuals were asked to digitally connect with every other student in the class on assignments, activities and reflections, which established a learning community in the classroom.

The students who seem to be quiet and disinterested were actually talking, planning and thinking about the questions raised in the class or in their respective groups after a few days of restructuring after a games-based strategy. Therefore, it was noticed that after the game had progressed, students became increasingly engaged and talkative. The peer observer frequently described students as "actively engaged", "on task", and "all a buzz" as they continued to play the 
game. As the questions were asked, students immediately started working on their responses before the teacher could finish reading the question and provide directions. Most of the students were eager to work together.

By the third and fourth days of playing GenkiEnglish games, students took more initiative and responsibility for their learning. They were ready with their electronic devices, such as iPads, and began to immerse themselves in the game as soon as they came into the classroom.

\section{Analysis of Research Question \#1}

The first research question was "What are students' perceptions and experiences in a classroom environment that includes a digital game for teaching and learning?"

The whole sample mentioned the GenkiEnglish games in their reflection sheets, indicating the games were fun, interesting and suggesting that it motivated them to learn. GenkiEnglish had an impact on students' perceptions and experiences in this type of learning environment.

Students, the teacher, and the researchers described the game and the classroom environment as cooperative and interactive, and students enjoyed the opportunity to learn while having fun. Their perceptions and experiences in a learning environment that used a game suggested that it was a memorable learning experience that changed students' attitudes and perceptions of school, and provided a more interesting and motivating classroom experience than these students were accustomed to. Students had to simultaneously balance working cooperatively and competitively while trying to accomplish their mission so that they could win the game. Playing a game in an elementary school class was a new experience many 
students had never encountered, and it provided a memorable way to learn, recall, and apply the course material.

The games allowed students the opportunity to apply course concepts while introducing them to learning English in a more memorable fashion.

The games also gave students control over their own learning environment. By playing the games, students were given control of the learning environment in a way that they had not experienced before. They were responsible for making decisions, solving problems, and deciding on what to learn and use for communication. Some students assumed leadership roles within their groups, but all students were equally responsible for helping their groups learn and make decisions.

\section{Analysis of Research Question \#2}

The second research question was "How is students' learning influenced by a digital game in the classroom?" One of the main themes that emerged from the qualitative data was knowledge, or what students learned. Students naturally discussed their new language learned without the teacher having to prompt a response in their reflection question about what they had learned.

\section{Analysis of Research Question \#3}

The third research question was "How are students' achievement goals enhanced by a digital game in the learning classroom?" Answers to this question appeared in the quantitative analyses, manipulating the achievement goals scale and the perceptions of the EFL motivational climate scale. Means and standard deviations for all measures are displayed in the following table. 
Table (1): Means and Standards Deviations of Students' Achievement Goals

\begin{tabular}{|r|r|r|}
\hline & $\mathrm{M}$ & SD \\
\hline \multicolumn{3}{|c|}{$\mid$} \\
\hline Goal orientations & & Achievement Goals \\
\hline Pre-ego & 3.22 & 0.96 \\
\hline Post-ego & 2.80 & 1.01 \\
\hline Pre-task & 4.24 & 0.67 \\
\hline Post-task & 4.03 & 0.75 \\
\hline \multicolumn{3}{|c|}{ Perceived Motivational Climate } \\
\hline Mastery & 3.42 & 0.54 \\
\hline Performance & 2.92 & 0.62 \\
\hline Beliefs about success & \multicolumn{1}{|c|}{} \\
\hline Motivation or effort & 3.84 & 0.61 \\
\hline Deception & 2.69 & 0.84 \\
\hline To facilitate com
\end{tabular}

To facilitate comparison between subscales, the researchers divided the total scores for each subscale by the number of items to generate a mean based on a five-point Likert-type response scale.

Two non-significant correlations emerged between preand post-study task and ego goal orientations ( $\mathrm{r}=.16$ and $\mathrm{r}=.08$, respectively), which confirmed the proposed orthogonally of the two goal orientations (Filippidis \& Tsoukalas, 2009). The results of these analyses showed that no significant changes in goal orientation had occurred over the course of the study. Consistent with achievement goal theory (Burguillo, 2010), the pre-study task and ego goal orientations served as the measure of dispositional goal orientation in all subsequent analyses. Descriptive statistics revealed that prior to and following the intervention, students scored high in task orientation and moderately high in ego orientation. However, observations of the class in the present study reveal that the sample tended to perceive the motivational climate to be more mastery than performance oriented. 


\section{Interpretations}

Much research has been conducted on the impacts of student-centred and active learning, but what does this really mean? It is more than just the design of student-centred activities and discussions to engage students in the academic content. It has to do with students' emotional, social, and psychological needs. It has to do with creating a socially supportive environment where students feel comfortable sharing their opinions and ideas. However, it took more than a well-designed student-centred learning activity to get these students involved. They needed the opportunity to establish a relationship with their peers before they could move on to the more digital learning activities the teacher had planned.

As stated earlier, Dickey (2011) believed that an experiential, supportive, challenging and compassionate learning environment will lead to enhanced student achievement where students feel they can take a risk and explore their interests within their own realms of reality. This is evident in a studentcentred learning environment, regardless of the types of digital games or activities that occur.

Dickey's (2011) view of experiential learning theory explained that student-centred learning creates favourable conditions and supportive environments that encourage students to achieve some level of selfactualization. Student-centred learning was evident in this class. Students' interests were placed first and foremost in the overall design and delivery of the course content.

Quantitative findings of the present study also demonstrate that perceptions of the digital game climate are associated with more adaptive motivational and affective patterns. Perception of a mastery climate related to gaming in the classroom was related to the 
attribution of success to motivation or effort. These are significant findings, as Swearingen (2011) suggested that achievement goals and beliefs about the causes of success are critical components of an individual's personal theory of achievement. The positive relationship that emerged between perception of a performance-oriented climate, and deception as a cause of success, suggests that students who are dependent on a favourable comparison to others, in order to feel successful, are likely to consider external factors, such as knowing how to impress the teacher, as adaptive forms of achievement. Such a belief, however, is not a sound basis for sustained and adaptive forms of achievement behaviour, as it relies on factors beyond a student's control. A fundamental tenet of achievement goal theory is that dispositional goal orientations and perceptions of the motivational climate are two independent dimensions of motivation affecting behaviour in achievement contexts (Sylven \& Sundqvist1, 2012). Support for this tenet was found with achievement goal orientations and perceptions of the motivational climate being investigated in the study. Perceptions of the climate are a significant predictor of students' responses, however, it suggests that these perceptions of digital learning environment can help motivate achievement in learning English as a foreignlanguage. 


\section{References}

1. Baek, Y. (2010). Gaming for classroom-based learning digital role playing as a motivator of study. Hershey PA, Information Science Reference. Retrieved from http://search.ebscohost.com/login.aspx?direct=true\&scop $\mathrm{e}=$ site $\& d \mathrm{~b}=$ nlebk $\& d b=$ nlabk $\& A N=310451$.

2. Bourgonjon, J., Valcke, M., Soetaert, R., De Wever, B., \& Schellens, T. (2011). Parental acceptance of digital game-based learning. Computers \& Education, 57(1), 1434-1444.

3. Burguillo, J. C. (2010). Using game theory and Competition based Learning to stimulate student motivation and performance. Computers \& Education, 55(2), 566-575.

4. Chen, Zhi-Hong, Liao, Calvin C. Y., Cheng, Hercy N. H., Yeh, Charles Y. C., Chan, Tak-Wai et al. (2012) Influence of Game Quests on Pupils' Enjoyment and Goal-Pursuing in Math Learning. Educational Technology \& Society, 15(2), 317-327.

5. Devlin, R. \& Nancy, B. S. (2010). Digital Simulation Games for Social Studies Classrooms. A Journal of Educational Strategies, Issues and Ideas, 83(4), 138144.

6. Dickey, M. D. (2011). Murder on Grimm Isle: The impact of game narrative design in an educational gamebased learning environment. British Journal of Educational Technology, 42(3), 456-469.

7. Eow, Y. et al. (2010) Computer games development and appreciative learning approach in enhancing students' creative perception. Computers \& Education, 54(1), 146-161.

8. Filippidis, S. K., \& Tsoukalas, L. A. (2009). On the use of adaptive instructional images based on the sequential-global dimension of the Felder-Silverman learning style theory. Interactive Learning Environments, 17(2), 135-150.

9. Fraser, B. (2002). Learning environments research: Yesterday, today and tomorrow. In Goh, S. C. \& Khine, M. S. (Eds.), Studies in educational learning environments: An international perspective (pp. 1-25). New Jersey: World Scientific. 
10. Frederick, P. (2010). Using Digital Game-Based Learning to Support Vocabulary Instruction for Developmental Reading Students. Unpublished doctoral dissertation. Nova Southeastern University.

11. Frederick, P. A. (2009). Using digital game-based learning to support vocabulary instruction for developmental reading students. Unpublished doctoral dissertation. Nova Southeastern University.

12. Fromme, J., \& Unger, A. (2012). Computer games and new media cultures: a handbook of digital games studies. Dordrecht, Springer. Retrieved from http://dx.doi.org/10.1007/978-94-007-2777-9.

13. Green, J. L., Camilli, G., \& Elmore, P. B. (2006). Handbook of complementary methods in education research. Mahwah, NJ: Lawrence Erlbaum Associates.

14. Kolenikov, S., Steinley, D., \& Thombs, L. A. (2010). Statistics in the social sciences: current methodological developments. Hoboken, NJ: Wiley.

15. Lecompte, M. D., Millroy, W. L., \& Preissle, J. (1992). The Handbook of qualitative research in education. San Diego: Academic Press.

16. Liu, E. (2011) Avoiding Internet Addiction when Integrating Digital Games into Teaching. Social Behavior and Personality: an international journal, 39(10), 1325-1335.

17. Liu, T. Y., \& Chu, Y. L. (2010). Using ubiquitous games in an English listening and speaking course: Impact on learning outcomes and motivation. Computers \& Education, 55(2), 630-643.

18. Meece, J. L., Blumenfeld, P.C., \& Hoyle, R. H. (1988). Students' goal orientations and cognitive engagement in classroom activities. Journal of Educational Psychology, 80, 514-523.

19. Rodgers, C. (2002). Defining reflection: Another look at John Dewey and reflective thinking. Teachers College Record, 104(4), 842-866.

20. Schneider, M. (2012). Exploring the potential of digital game based learning in the EFL classroom. GRIN Verlag, NY. 
21. Swearingen, D. (2011). Effect of Digital Game Based Learning on Ninth Grade Students' Mathematics Achievement. Unpublished doctoral dissertation. The University of Oklahoma.

22. Sylven, L. and Sundqvist, P. (2012). Gaming as Extramural English L2 Learning and L2 Proficiency among Young Learners. ReCALL, 24(3), 302-321.

23. Treasure, D. (1997). Perceptions of the motivational climate and elementary school children's cognitive and affective response. Journal of Sport \& Exercise Psychology, 19, 278-290.

24. VAN Manen, M. (1990). Researching lived experience: human science for an action sensitive pedagogy. [Albany, N.Y.], State University of New York Press.

25. Wang, Y. H., \& Liao, H. C. (2011). Adaptive learning for ESL based on computation. British Journal of Educational Technology, 42(1), 66-87.

26. Yang, Y. (2012). Building Virtual Cities, Inspiring Intelligent Citizens: Digital Games for Developing Students' Problem Solving and Learning Motivation. Computers \& Education, 59(2), 365-377. 


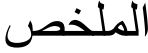

هدفت الدراسة الحالية إلى معرفة تصورات الطلبة وخبراتهم نحو

بيئة التعلم القائمة على الألعاب الرقمية، ومعرفة مدى اسهامها في زيادة

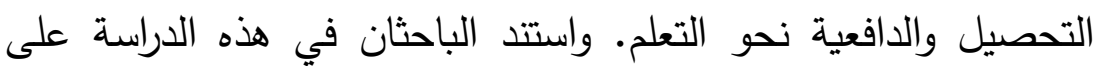
أساس نظري مفاده أن لبيئة التعلم أثراً قوياً من شأنه أن يؤثر في تكوين تصورات الطلبة واثراء خبراتهم في العملية التعليمية. فقد شملت الدراسة على عينة مقصودة من • ب تلميذاً في المرحلة الابتدائية استخدموا فئها برنامجاً تكنولوجياً رقمياُ كأداة للتعلم. وقد شارك التلائ بكيذ بكتابة انطباعاتهم حول بيئة التعلم الصفية المحيطة بهم، ومن ثم تمت ملاحظة ردود أفعالهم من قبل معلم الفصل. وقام الباحثان بجمع البيانات وتصنيفها حسب الأفكار التي تضمنتها، مستخدمين بذلك المنهج الكيفي والكمي معاً، وعلاوة على ذلك تم استخدام استبانة خاصة بإنجاز

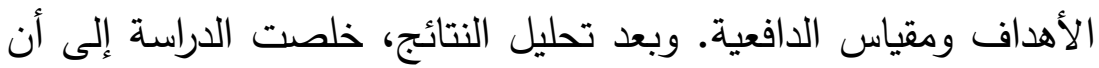
استخدام الألعاب الرقمية في التدريس له أثر إيجابي على تصورات الطلبة حول بيئة التعلم، مما قد يسهم في زيادة دافعيتهم واقبالهم نحو التعلم، وأن على القائمين على استخدام الألعاب الرقمية في التعلم مراعاة

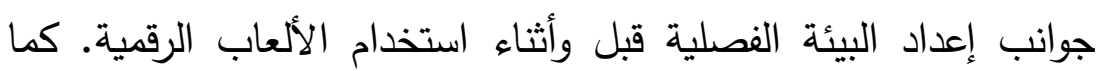
أوصت الدراسة على تشجيع المعلمين على استخدام الألعاب الرقمية

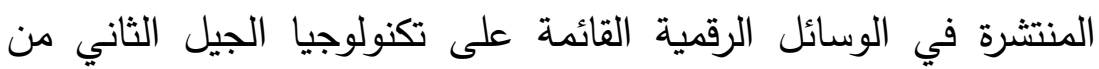




\begin{abstract}
The present study examined the effects of students' perceptions and experiences in a learning environment that included a digital game as a teaching and learning tool. The researchers indicate that the learning environment is a powerful force to influence students' perceptions and experiences of the educational process. Thirty students participated in the study, sharing their insights and experiences about their perceptions of this type of learning environment. Using students' written reflections, researchers-as-observers feedback, and the teacher's research journal, data were coded and then analyzed to reflect common themes in students' perceptions and experiences of the classroom as a whole. Findings from an Achievement Goals Questionnaire and a Perceived Motivating Climate Scale were extracted. Qualitative and quantitative data indicate that digital games in a learning environment, and perception of mastery in this environment, had a positive influence on the learning environment. The study encouraged teachers to use digital games based on web 2.0 technologies.
\end{abstract}

